\title{
PLAYLISTS: Cinematic Anthropology
}

\author{
PAUL SHANKMAN \\ LAUREN BERLANT \\ STEVEN ROBINS \\ CHARLES HIRSCHKIND \\ ANAND PANDIAN
}

\section{PAUL SHANKMAN (University of Colorado, Boulder)}

This visual playlist is an eclectic mix of one documentary that pushes the envelope of the genre, two that examine climate change in the Pacific, two that are historical remembrances of the civil rights era, and one cult movie that is a guilty pleasure.

Sweetgrass (2009): This exceptional film by Ilisa Barbash and Lucien CastaingTaylor is an evocation of a summer sheep drive through the Montana wilderness. Yes, a sheep drive. The exquisite imagery must be seen on the big screen to be appreciated.

There Once Was An Island (Briar March, 2010) and Sun Come Up (Jennifer Redfearn, 2011): Documentaries about the wrenching dilemmas facing people on tiny islands in the Pacific that are threatened by climate change and related problems. Their poignant stories are great for courses.

Freedom Summer (Stanley Nelson, 2013): Set in Mississippi in the summer of 1964. College students from the north risked their lives to join local African Americans in supporting summer programs for kids and voter registration drives for adults. Think you know this story? Think again. Freedom Riders (Stanley Nelson, 2010) is another excellent documentary 
about civil rights activists and their harrowing experiences, this time desegregating interstate buses in the deep South in 1961.

Joe Versus the Volcano (John Patrick Shanley, 1990): Need a break? Try this quirky comedy about a down-on-his-luck ordinary Joe (Tom Hanks) who volunteers to save people on the tropical island of Waponi Woo by jumping into their volcano (known as the Big Woo). As he voyages by yacht across the Pacific with Meg Ryan, things get complicated. Not for everyone. Note that director John Patrick Shanley had already earned a screenplay Oscar for Moonstruck (1987).

\section{LAUREN BERLANT (University of Chicago)}

Here is a list that isn't curated except by the metric of recency. I hope that the impulse toward taste-curation that might be implied here will not here be implied. I have been sitting with these for work and have learned a lot from them over the years, and recently, etc. Their resonance with the present moment will be pretty clear, I think, which happened accidentally and unfortunately, as well as fortunately.

Finally Got the News (1970): A documentary by the League of Revolutionary Black Workers evidencing its fight against big auto and the United Mine Workers too, as well as its struggles to understand and overcome barriers to white-black working-class solidarity.

Wattstax (Mel Stuart, 1973): A concert film of a concert that commemorated the 1965 Watts riots. Richard Pryor offers much inset comedy/commentary. It is very political. It is very sentimental but with an edge that historicizes the politics of uplift, of optimism, of revolutionary consciousness, and ordinary political instruments.

Let the Fire Burn (Jason Osder, 2013): A found-footage documentary of the Philadelphia police's assassination of the Move neo-African organization-police brutality, white clueless, racism, empathically stunned media and the like. Frank Rizzo, monster. Other bureaucrats, banality of evil. A resonating intimate other to John Edgar Wideman's Philadelphia Fire (New York: Henry Holt, 1990).

In the Year of the Pig (Emile de Antonio, 1968): A found-footage documentary of the mediated exposure of and numbness toward the Vietnam War, a teaching in the relation of the numb to the unbearable (each expanding in its own way) and the politics of disbelief. 
Born in Flames (Lizzie Borden, 1983): Another film of the violent, policebrutal, racist, homophobic, hetero-normative, imperialist present, shot in and thinking about documentary style but not a documentary-science fiction, actually, in its own way, sometimes, a genre of disbelief. It produces more pleasure that feels like pleasure than the films listed above.

What Faroki Taught (Jill Godmillow, 1968): A remake of Harun Farocki's black and white, German film Inextinguishable Fire (1969), about Vietnam, napalm, bureaucracy, the centrality of conversation to politics, the question of state violence as counter-revolutionary and what that means for revolutionary imaginaries whose reparativity involves destruction.

\section{STEVEN ROBINS (Stellenbosch University)}

Roger and Me (1989): Michael Moore's classic agitprop documentary, with a difference. Its strength is its ethnographic rootedness in Moore's hometown, Flint, Michigan. Moore really knows this town well and his personal connection to it gives the documentary its filmic power.

Capitalism: A Love Story (2009): Roger Moore's polemical and racy critique of contemporary capitalism. It is a useful complement to Roger and Me and usually generates much student discussion. Screening the film along with good readings on late capitalism enhances its pedagogical value.

Ochre and Water (2001): Craig Mathew's thought-provoking ethnographic film that focuses on the Namibian government's plans to construct a dam that would flood the land of the semi-nomadic Himba community. The film tracks the efforts by the Himba, and their anthropologist and NGO allies, to challenge the dam's construction. It also draws attention to a complicated cultural politics of "strategic essentialism" that indigenous communities sometimes deploy in struggles against powerful states.

Death by Myth (2001), the fifth and final part of John Marshall's Kalahari Family series (1951-2001): A powerful ethnographic film that captures Marshall's own role in San rural development interventions in Namibia. It is somewhat of an autocritique by a filmmaker who has been central in producing ethnographic representations of the San over a number of decades. It can be complemented with texts relating to the Great Kalahari San Debate, for example, the writings of Edwin Wilmsen and Richard Lee.

City of God (Fernando Meirelles and Kátia Lund, 2002) and Waste Land (Lucy Walker, João Jardim, and Karen Harley, 2010): Two Brazilian films that 
provide powerful graphic imagery of contemporary urban life in Brazil and elsewhere in the global South. Both of these films can be complemented by ethnographic texts by Teresa Caldeira and John Holston.

\section{CHARLES HIRSCHKIND (University of California, Berkeley)}

A cinematic introduction to the discipline of anthropology:

Caché (Michael Haneke, 2005): As close an analysis of France's postcolonial psyche as can be found.

Postcards from Tora Bora (Wazhmah Osman, 2007): A woman returns to the war-scarred country and city of her childhood, tracking down her memories in the fragments of a once hospitable world now in ruins.

The Enigma of Kaspar Hauser (Werner Herzog, 1974): A wild child, there at the birth of anthropology.

Safe (Todd Haynes, 1995): A tale of self-fashioning and survival in the toxic suburbs of Los Angeles.

Battle of Algiers (Gillo Pontecorvo, 1966): A story of anti-colonial resistance in Algeria, or is it Palestine, Iraq, Afghanistan . . . ?

\section{ANAND PANDIAN (Johns Hopkins University)}

Everything these days looks and feels so much like cinema - what to do for footing in the midst of this slippery stream of images?

\section{Plastic Earth, the Movie}

So you're trawling the feed like you always do when the kids are in bed and the dishes are done, and you notice something else making the rounds about the world's troubles, a tale of "plastiglomerates" washing up on the beaches of Hawaii, composed of molten plastic and volcanic rock (1). Ever more baroque reasons to worry over the fate of this earth, you think to yourself, the flickering life of this "Great Ball on Which We Live" (2). There was a time when everyone thought such images would suffice to set things right, a bit of perspective, like all of us sailing together on a small blue marble through the vastness of space (3). Now, it's more like that movie you once saw, the one where Sam Rockwell plays a helium miner stranded on the moon — now, it's the earth itself that feels so far from reach (4). You remember that fable by Calvino, the one where the earth passes so close to its lunar companion that people could lean out with buckets to scoop the fermented milk pooling in its craters (5). Islands grown from taro- 
wrapped bundles, stones that whirl with the spirits of the dead, bones laid out as pipestem corals - you wonder what it would take to grasp the plastic promise of such myths once again (6).

1. Corcoran, Patricia L., Charles J. Moore, Kelly Jazvac. 2014. “An Anthropogenic Marker Horizon in the Future Rock Record.” GSA Today 24, no. 6: 4-8. http://dx.doi.org/10.1130/GSAT-G198A.1.

2. Agee, James, and Walker Evans. 2001. Let Us Now Praise Famous Men. Boston: Houghton Mifflin. Originally published in 1941.

3. Poole, Robert. 2008. Earthrise: How Man First Saw the Earth. New Haven, Conn.: Yale University Press.

4. Jones, Duncan, director. 2009. Moon. Culver City: Stage 6 Films.

5. Calvino, Italo. 1968. Cosmicomics. New York: Harcourt.

6. Leenhardt, Maurice. 1979. Do Kamo: Person and Myth in the Melanesian World. Chicago: University of Chicago Press. 